\title{
COMBATING UnREgUlATED FiSHING THROUGH UNILATERAL TRADE MEASURES: A TIME FOR CHANGE IN INTERNATIONAL FISHERIES LAW?
}

\section{Osvaldo Urrutia*}

\begin{abstract}
Unregulated fishing on the high seas - understood as fishing activities by vessels flagged to a nonmember state in an area regulated by a regional fisheries management organisation - are a significant threat to the sustainability of high seas fishery resources. The European Union (EU) and the United States - two major market destinations for fishery products - have shown a strong determination to treat unregulated fishing as illegal fishing. They have applied or threatened to apply trade restrictions to states that have no treaty obligations to refrain from fishing on the high seas. These actions are conspicuous because the practical effect of these unilateral measures entails a challenge to the fundamental pacta tertiis rule. This article suggests that the application of unilateral trade-related measures by the EU and the United States against non-member states represents relevant state practice for the formation of a prohibition against unregulated fishing in customary international law.
\end{abstract}

\section{INTRODUCTION}

Unregulated fishing activities on the high seas - fishing by vessels flagged to a non-member state in an area regulated by a regional fisheries management organisation - are a threat to the sustainability of high seas fishery resources and a significant challenge to the international legal order of the oceans. The European Union (EU) and the United States - two major market destinations for fishery products - have shown a strong determination to give unregulated fishing the same treatment as illegal fishing. Interestingly, they have applied or threatened to apply import bans or restrictions on fishing trade to states that have no treaty obligations to refrain from fishing in the high seas. These actions are

* Lecturer in international law, Pontificia Universidad Católica de Valparaíso, Chile; and PhD student, Victoria University of Wellington. The author wishes to thank Professor Campbell McLachlan QC, Associate Professor Joanna Mossop and PhD student Nathan Ross for their valuable comments on early drafts of this article. Any errors are the author's sole responsibility. 
conspicuous because the practical effect of these unilateral measures entails a challenge to the fundamental pacta tertiis rule.

This article suggests that the application of unilateral trade-related measures by the EU and the United States against non-member states represents relevant state practice for the formation of customary international law in the treatment of unregulated fishing. This is practice coming from specially-affected states that is beyond the mere performance of treaty obligations and is contributing to an evolutionary change in opinio juris.

The article will first introduce the topic and the legal problem that the trade measures taken by the EU and the United States are targeting. Part III will briefly describe the legal framework in the EU and the United States against states sponsoring unregulated fishing, with reference to specific cases. Part IV will explain why these measures should be considered as relevant state practice for the formation of customary law. It is beyond the scope of this article to address the question of whether there is a consolidated or emerging customary rule against unregulated fishing on the high seas, although there are good arguments for such a case and some scholars have suggested it.

\section{DEFINING UNREGULATED FISHING}

\section{A Background}

There is ample evidence about the worrying status of marine fishery resources. In 2015 more than 33.1 per cent of fish stocks worldwide were fished at biologically unsustainable levels (overexploited), whereas maximally sustainably fished stocks accounted for 59.9 per cent. ${ }^{1}$ Although there are some encouraging cases of good management and fish stock recovery, the overall trend is alarming, and the problem exists both in areas under and beyond national jurisdiction. On the high seas global figures are difficult to obtain with accuracy but there are no reasons to be optimistic. The Food and Agriculture Organization of the United Nations (FAO) estimates that among the seven principal tuna species, 43 per cent of the stocks were estimated as being fished at biologically unsustainable levels in $2015 .^{2}$ Iconic highly migratory species such as the bluefin tuna are exploited at far from sustainable levels. ${ }^{3}$

1 Food and Agriculture Organization of the United Nations The State of World Fisheries and Aquaculture 2018: Meeting the Sustainable Development Goals (2018) at 40, also known as the SOFIA Report. Maximally sustainably fished stocks (what the FAO labelled as "fully exploited" in previous versions of the SOFIA Report) does not mean over-exploitation; rather, it refers to stocks where there is no more room for expansion. Illegal and unregulated activities, which are generally unreported add uncertainty to these numbers.

2 At 42 .

3 The 2017 assessment undertaken by the Scientific Committee of the Commission for the Conservation of Southern Bluefin Tuna (CCSBT) suggested that the bluefin stock remain at a low state and below the level to produce maximum sustainable yield: Commission for the Conservation of Southern Bluefin Tuna Report of the Twenty Second Meeting of the Scientific Committee (September 2017) at [104]. 
Responding to this problem, states with an interest in the management and exploitation of stocks occurring there - including straddling and highly migratory stocks - have set up international organisations with specific mandates to adopt management measures for their sustainable use. Although definitions and powers vary in scope, they are commonly known as regional fisheries management organisations or regional bodies. ${ }^{4}$

These organisations face two main challenges: the need to improve management of stocks and species at regional level and responding to those who do not abide by international rules. The latter idea is captured in the concept of illegal, unreported and unregulated fishing (IUU fishing), a much criticised notion ${ }^{5}$ that nevertheless has been widely accepted in international practice since its first adoption in a global instrument in $2001 .^{6}$ Although they are often treated together, illegal and unregulated activities mean different things. On the high seas, illegal activities are those carried out against the rules adopted by a regional fisheries organisation by vessels flagged to member states. Unregulated fishing, in contrast, are those activities undertaken by vessels flagged to a state or entity that is neither a member nor a cooperating party of the relevant regional organisation. In other words: unregulated fishing refers to fishing against the rules of the relevant international organisations by vessels flagged to non-member states.

Like the most detrimental aspects of illegal fishing, unregulated activities also cause harmful impacts on high seas stocks. Unregulated fishing disregards catch limits, frequently employs environmentally damaging techniques and does not observe seasonal or area-based restrictions. These vessels are usually flagged to states that have no capacity or will to exert any meaningful control, often referred to as flags of convenience. ${ }^{7}$ Precise figures about unregulated catches on the high seas

4 The notion of "regional arrangements" should also be considered. Regional arrangements are less formal than a regional organisation created by treaty, but in practice their measures are similar. This article will mostly refer to regional fisheries management organisations, as state practice concerning the latter is sometimes not as extensive as it is in the former.

5 Andrew Serdy "Pacta Tertiis and Regional Fisheries Management Mechanisms: The IUU Fishing Concept as an Illegitimate Short-Cut to a Legitimate Goal" (2017) 48 ODIL 345; Andrew Serdy The New Entrants Problem in International Fisheries Law (Cambridge University Press, Cambridge, 2016); and Jens T Theilen "What's in a Name? The Illegality of Illegal, Unreported and Unregulated Fishing" (2013) 28 IJMCL 533. See also Rachel J Baird Aspects of Illegal, Unreported and Unregulated Fishing in the Southern Ocean (Springer, Berlin, 2006) at 12. Unreported fishing is recognised as illegal by most international regulations and generally regarded as a subset of IUU fishing.

6 International Plan of Action to Prevent, Deter and Eliminate Illegal, Unreported and Unregulated Fishing (adopted at the 24th session of the FAO Committee of Fisheries on 2 March 2001, endorsed by the 120th Session of the FAO Council on 23 June 2001).

7 Unregulated fishing occurring recently on Antarctic waters is illustrative. For more than a decade, six unregulated vessels operated on toothfish, a high-value fishery managed by the Commission for the Conservation of Antarctic Marine Living Resources (CCAMLR). They were flagged to non-CCAMLR members and operated with full disregard of the conservation measures adopted by this organisation. The "Asian Warrior", for example, changed its name 17 times between 2003 and 2018, and was flagged to at least 
are difficult to obtain because they are unreported. As stock assessments can barely estimate the figures, unregulated fishing affects sustainable fisheries management.

\section{B The Legal Problem}

Unregulated fishing has been able to persist primarily through the operation of two old rules of international law: the freedom of fishing on the high seas and the near-exclusive jurisdiction of the flag state. It is not difficult to see why the well-entrenched principle of the freedom of the high seas, a 400-year-old Grotian notion based on the endless bounty of the open seas, is not suitable for the sustainable exploitation of common goods in the 21 st century. The law of the sea recognises the flag state as the main jurisdiction entitled to regulate, control and enforce international rules beyond areas under national jurisdiction, ${ }^{8}$ but evidence suggests there are still many flag states with little capacity - or will - to ensure this happens. ${ }^{9}$

The international community has made important efforts to curb the old Grotian notion and has encouraged states to act responsibly to manage fishery resources on the high seas. These have come mostly by states agreeing and adopting treaties containing express obligations. The 1982 United Nations Convention on the Law of the Sea (UNCLOS) established a general duty for coastal and distant water fishing nations to cooperate in the adoption of management rules for the high seas. ${ }^{10}$ Despite the broad success of UNCLOS, the general duty to cooperate early on proved insufficient to serve as an efficient legal framework and to play any substantive role in constraining the most negative aspects of unregulated fishing on the high seas. Under UNCLOS there is no obligation to cooperate through a specific body or organisation for the adoption of high seas fisheries measures, and therefore regional bodies do not have any pre-eminent status.

States have since then continued setting up and empowering several regional fisheries management organisations with the competence to regulate resources that occur on the high seas, including straddling and highly migratory stocks. ${ }^{11}$ An important milestone in this regard was the

nine countries, including Equatorial Guinea, Tanzania, Indonesia, Sierra Leone, North Korea and Saint Vincent and the Grenadines. Only concerted actions by several states and unilateral measures by market destinations resulted in meaningful action against some of these vessels.

8 Mary Ann Palma, Martin Tsamenyi and William Edeson Promoting Sustainable Fisheries: The International Legal and Policy Framework to Combat Illegal, Unreported and Unregulated Fishing (Martinus Nijhoff, Leiden, 2010) at 110 .

9 Dana D Miller and U Rashid Sumaila "Flag Use Behaviour and IUU Activity within the International Fishing Fleet: Redefinitions and Identifying Areas of Concern" (2014) 44 Marine Policy 204.

10 See for example arts 63-64 and 117-118 of the United Nations Convention on the Law of the Sea 1833 UNTS 3 (opened for signature 10 December 1982, entered into force 16 November 1994) [UNCLOS]. State practice and most scholars seem to confirm this duty as a customary obligation.

11 There are approximately 17 regional fisheries organisations, or arrangements that in practice work as organisations (for example, through decisions of the meeting of the contracting parties), with the capacity to 
1995 United Nations Fish Stocks Agreement (UNFSA). ${ }^{12}$ This treaty establishes that when there is a regional fisheries body regulating high seas stocks, states whose vessels want to fish in the area must become party to that organisation or agree to apply its measures, otherwise they shall not authorise their vessels to fish. ${ }^{13}$ In effect, a state that accedes to the UNFSA accepts the obligation not to undertake unregulated activities; unregulated fishing becomes illegal for that contracting party by virtue of its treaty commitments.

The UNFSA concept was supplemented with the adoption in 2001 of the FAO International Plan of Action to Prevent, Deter and Eliminate Illegal, Unreported and Unregulated Fishing (FAO Plan of Action). ${ }^{14}$ The 2009 FAO Port State Measures Agreement added to this evolution by recognising the very same definition of the FAO International Plan of Action. ${ }^{15}$ Regional fisheries bodies today recognise the same notion of unregulated fishing, including those that have been established after UNFSA, and they generally treat fishing by non-members as contrary to the rules of their organisations. ${ }^{16}$

This evolution is encouraging, and it has meant significant change in treaty obligations, but it leaves the core legal problem intact: according to the universally-accepted pacta tertiis rule, treaty

adopt binding conservation measures for different stocks occurring on the high seas. Some examples of regional fisheries bodies include the Western and Central Pacific Fisheries Commission (WCPFC), the InterAmerican Tropical Tuna Commission (IATTC), the Northwest Atlantic Fisheries Organization (NAFO) and the South Pacific Regional Fisheries Management Organisation (SPRFMO), to mention a few.

12 Agreement for the Implementation of the Provision of the United Nations Convention on the Law of the Sea of 10 December 1982 relating to the Conservation and Management of Straddling Fish Stocks and Highly Migratory Fish Stocks 2167 UNTS 3 (opened for signature 4 December 1995, entered into force 11 December 2001). Today it has 89 contracting parties.

13 Articles 8(3)-(4) and 17.

14 International Plan of Action to Prevent, Deter and Eliminate Illegal, Unreported and Unregulated Fishing, above $n$ 6, at [3.3.1] recognised the notion behind arts 8(3)-(4) and 17 of the UNFSA: unregulated fishing refers to fishing activities "in the area of application of a relevant regional fisheries management organization that are conducted by vessels without nationality, or by those flying the flag of a State not party to that organization, or by a fishing entity, in a manner that is not consistent with or contravenes the conservation and management measures of that organization". At [3.3.2] the Plan of Action included an additional category within the notion of "unregulated fishing" which for the purposes of this article is not relevant.

15 Agreement on Port State Measures to Prevent, Deter and Eliminate Illegal, Unreported and Unregulated Fishing (opened for signature 4 December 1995, entered into force 5 June 2016). Today it has 56 contracting parties.

16 See for example art 1(1)(j) of the Convention on the Conservation and Management of High Seas Fishery Resources in the South Pacific Ocean (opened for signature 1 February 2010, entered into force 24 August 2012); and Conservation Measure 08/06 establishing a List of Vessels Presumed to Have Carried Out Illegal, Unreported and Unregulationed Fishing Activities in the South-East Atlantic Fisheries Organisation (SEAFO) Convention Area (adopted by the Parties to the South East Atlantic Fisheries Organization Convention, approved 4 April 2006). 
provisions do not apply to fishing vessels flagged to a non-party state. ${ }^{17}$ By treaty law, if a fishing vessel is flagged to a non-member state the provisions of that treaty do not impose any obligation on them. The consequences of the strict application of the pacta tertiis rule have historically led to the existence of the so-called flags of convenience: free riders that fish under the flag of a non-party, whose control capacity is often weak or non-existent. They have for long operated outside the legal framework agreed by international organisations, undermining their management efforts and triggering an incentive for others to defect from the rules.

Facing this challenge, states and regional fisheries organisations have adopted different strategies to deal with the limitations of the high seas legal framework and weak or non-cooperative flag states. Because they can occur in any part of the high seas, combating unregulated fishing requires the exercise of diverse measures demanding different jurisdictional capacities: flag state, port state, the state of the nationality and the market state. They all have a relevant jurisdictional link.

Although the freedom of the high seas entails the jurisdictional primacy of the flag state, ${ }^{18}$ the persistence of unregulated activities strongly indicates that a considerable number of them than have failed to exercise it responsibly. Resting solely on the jurisdiction of the flag state is simply not enough. Therefore, some states have adopted bolder measures beyond the scope of targeting the vessels implicated in unregulated fishing. Instead, they seek to block market access to fishery products coming from flag states whose vessels have engaged in unregulated fishing. The following parts focus on the measures adopted in this regard by the EU and the United States.

\section{THE EUROPEAN UNION AND UNITED STATES APPROACHES}

Among the many states that participate in the multilateral and decentralised system of fisheries governance in the high seas, the EU and the United States have played pivotal roles. ${ }^{19}$ They participate as active members, regularly flag vessels to fish in several regional fisheries bodies, ${ }^{20}$ and are

17 Vienna Convention of the Law of Treaties 1155 UNTS 331 (opened for signature 23 May 1969, entered into force 27 January 1980), art 34.

18 UNCLOS, arts 91 and 94.

19 The legal status of the EU as an international organisation is well-known. For the sole benefit of keeping the language simple, this article will refer to the United States and the EU as "states". See n 87 below.

20 In the case of the United States this includes, among others, the Western and Central Pacific Fisheries Commission (WCPFC), the International Commission for the Conservation of Atlantic Tunas (ICCAT), the Northwest Atlantic Fisheries Organization (NAFO), the North Pacific Fisheries Commission (NPFC) and the Commission of the South Pacific Regional Fisheries Management Organisation (SPRFMO). The EU actively participates in many of these agreements, including the North-East Atlantic Fisheries Commission (NEAFC), NAFO, WCPFC, ICCAT and SPRFMO. 
conspicuous market destinations for fishery products. ${ }^{21}$ Concern for the sustainability of international fisheries is not new in the United States and EU and their active civil society has contributed to bringing ocean sustainability and IUU fishing to the top of the environmental agenda. The United States and the EU have been active promoters and supporters of multilateral actions against illegal and unregulated fishing and their domestic legislations are consistent with that approach. ${ }^{22}$ In this context, it comes as no surprise that they have pioneered unilateral responses to IUU fishing. The application of these measures shows that in practice the EU and the United States are treating unregulated fishing as if they were illegal activities, and therefore blurring the distinction.

Trade or market-related measures broadly seek to impose objective conditions on fishery products to enter a market or to deny access to a product in case those conditions are not met. Margaret Young has proposed to classify these measures in two groups: on the one hand, traceability and import restrictions, and import bans or market denial measures on the other. ${ }^{23}$ Both categories can have a multilateral or unilateral origin. Regional fisheries organisations have for years operated certification schemes in relation to some resources and member states implement them at domestic level. The EU and the United States have also adopted and are implementing unilateral trade and certification schemes targeting illegal and unregulated catches through the control of imports. ${ }^{24}$ Although these measures are very positive, certification schemes have some limitations, and the "laundering" of catches can occur through different means - not least through transhipments at sea. Therefore, targeting vessels and catches is necessary but not enough. The novel and bold approaches by the EU and the United States of directly aiming at the flag state with import bans or market denial measures mean a progressive change that plays a substantially more effective role in combating unregulated fishing. A state that may be threatened with a denial of market access for its fishery exports due to a failure to control one or two fishing vessels will certainly be encouraged or forced to stop free-riding on international rules.

21 The EU represents the largest single market for fish and fishery products, followed by the United States and Japan. In 2016, six members of the EU (Spain, France, Italy, Germany, Sweden and the United Kingdom) accounted for approximately 25.3 per cent of the total value of world imports of fish and fish products. The United States is the second largest importer, representing 15.1 per cent the same year, followed by Japan with 10.2 per cent: The State of World Fisheries and Aquaculture 2018, above n 1, at 55.

22 For example, as early as 2006 the EU submitted to CCAMLR a proposal allowing for the adoption of traderelated measures against contracting parties and non-contracting parties to CCAMLR in cases of IUU fishing. The EU continued presenting proposals or discussion papers to this aim until 2014. The required consensus was opposed by several delegations for reasons that did not relate to the broad aim of combating IUU fishing.

23 Margaret Young "International trade law compatibility of market-related measures to combat illegal, unreported and unregulated (IUU) fishing" (2016) 69 Marine Policy 209 at 210.

24 Under EU Regulation 1005/2008 establishing a Community system to prevent, deter and eliminate illegal, unreported and unregulated fishing [2008] OJ L286/1, the EU has implemented a catch certification scheme. In the case of the United States, see Final Rule on Seafood Traceability Program Title 50 CFR 300.324 (effective 9 January 2017). 
To be sure, states and organisations such as the EU can adopt unilateral trade measures to restrict or prevent access to their market of certain goods, provided they conform to the rules and exceptions of the World Trade Organization agreements, not least the General Agreement on Tariffs and Trade (GATT 1994) ${ }^{25}$ and the Agreement on Technical Barriers to Trade. ${ }^{26}$ Young has correctly argued that these unilateral measures appeared to have been designed to ensure that they are fair, transparent and non-discriminatory. ${ }^{27}$ She has also demonstrated, in the case of unilateral trade measures addressing climate change - which can be reasonably compared in several grounds to those against IUU fishing - that they are unlikely to violate or enliven public international law rules on territorial jurisdiction because the importing country is regulating behaviour within or at its borders and therefore has a territorial basis for jurisdiction. ${ }^{28}$ It seems that, at least prima facie, if well designed and implemented, these measures may not represent a challenge to international trade rules. Moreover, the aim to combat IUU fishing conforms to legitimate objectives expressly recognised in trade law, including the protection of animal or plant life or health, or the environment. ${ }^{29}$ What this article wishes to highlight is that, despite the conceptual differences and dissimilar legal nature of illegal and unregulated fishing, the EU and the United States are treating them both as illegitimate and are threatening states promoting or sponsoring these activities with the same negative consequences through unilateral measures. In the context of combating IUU fishing, they add to the array of international and domestic actions having potential implications to develop a customary change in the rules governing high seas fisheries.

25 General Agreement on Tariffs and Trade 1867 UNTS 190 (opened for signature on 15 April 1994, entered into force 1 January 1995).

26 Agreement on Technical Barriers to Trade 1868 UNTS 120 (opened for signature 15 April 1994, entered into force 1 January 1995).

27 Young, above n 23, at 215.

28 Margaret Young "Trade measures to address climate change: territory and extraterritoriality" in Panagiotis Delimatsis (ed) Research Handbook on Climate Change and Trade Law (Edward Elgar Publishing, Abingdon, 2016) 329 at 350.

29 Young, above n 23, at 215. 


\section{A The European Union Regulation}

\section{Import bans to non-cooperating non-European Union states}

The EU adopted on 29 September 2009 Regulation 1005/2008, establishing a Community system to prevent, deter and eliminate IUU fishing (the EU Regulation). ${ }^{30}$ It explicitly covers unregulated activities on the high seas. ${ }^{31}$

Chapter VI of the EU Regulation establishes a system to identify non-cooperating non-EU states aimed at those states failing to cooperate in the fight against IUU fishing. ${ }^{32}$ A non-EU country may be identified as non-cooperating: ${ }^{33}$

$\ldots$ if it fails to discharge the duties incumbent upon it under international law as flag, port, coastal or market State, to take action to prevent, deter and eliminate IUU fishing.

The EU system works out in practice like a traffic light scheme: yellow (pre-identification warning), ${ }^{34}$ red (identification, listing and sanctions) and green lights (lifting of warnings or sanctions). ${ }^{35}$ The most important consequence for identified and listed non-cooperating third states is the trade ban established in Article 38:

... the importation into the Community of fishery products caught by fishing vessels flying the flag of

such countries shall be prohibited, and accordingly catch certificates accompanying such products shall not be accepted.

There are no differences in the consequences attaching to illegal and unregulated activities, and therefore fishing by non-members states in areas regulated by a regional body may be subject to unilateral trade measures of this kind.

\section{A definition of unregulated fishing consistent with international instruments}

Paragraph 4 of Article 2 of the EU Regulation defines unregulated fishing as part of the "illegal, unreported and unregulated" notion, consistently with the terms of international instruments and the 2001 FAO Plan of Action. Article 3 of the EU Regulation refers specifically to the specific kind of

30 Regulation 1005/2008, above n 24. See in general Martin Tsamenyi and others "The European Council Regulation on Illegal, Unreported and Unregulated Fishing: An International Fisheries Law Perspective" (2010) 25 IJMCL 5.

31 Regulation 1005/2008, above n 24, arts 1(3) and 2(4).

32 Article 31

33 Article 31(3).

34 Article 32. The Commission opens a dialogue for six months.

35 Article 33(2) regarding identification, and arts 33 and 35 concerning listing. 
unregulated activities this article has described, that is, those by non-members to regional fisheries bodies:

Fishing vessels engaged in IUU fishing

1. A fishing vessel shall be presumed to be engaged in IUU fishing if it is shown that, contrary to the conservation and management measures applicable in the fishing area concerned, it has:

$\cdots$

k) carried out fishing activities in the area of a regional fisheries management organisation in a manner inconsistent with or in contravention of the conservation and management measures of that organisation and is flagged to a State not party to that organisation, or not cooperating with that organisation as established by that organisation ...

Therefore, the activities that the EU is seeking to tackle by this Regulation include those undertaken by non-members to the relevant regional fisheries organisation. Several provisions of the Regulation confirm this, including arts 11 and 31(6)(b).

\section{Enforcing the European Union Regulation against unregulated fishing activities}

The EU measure has seen the assessment of over 50 non-EU countries and fishing entities and 25 had received pre-identification notifications by May $2018 .{ }^{36}$ Of them, the EU has identified and listed six, ${ }^{37}$ and only three remain currently listed according to ch VI of the EU Regulation. ${ }^{38}$ The whole process of identification, listing or delisting is not fully in the public domain and it does not allow for access to the complete responses of the targeted states, which makes it difficult to completely understand some of the motivations behind the EU decisions.

Nevertheless, the EU publishes the decisions notifying the "yellow" and "red cards". Some of them contain enough details to assess how the EU treats IUU fishing in general and unregulated fishing in particular. Most of the states identified under the EU Regulation have been included for infringing relevant treaty provisions, including obligations as flag and port states, and measures adopted by regional fisheries management organisations. They match the definition of illegal fishing stricto sensu.

36 Belize, Cambodia, Comoros, Curacao, Fiji, Ghana, Kiribati, Korea, Liberia, Panama, Papua New Guinea, Philippines, Republic of Guinea, Sierra Leone, Solomon Islands, Sri Lanka, St Kitts and Nevis, St Vincent and the Grenadines, Chinese Taipei/Taiwan, Thailand, Togo, Trinidad and Tobago, Tuvalu, Vanuatu and Vietnam.

37 Belize, Cambodia, Comoros, Republic of Guinea, Sri Lanka, and St Vincent and the Grenadines.

38 Cambodia, Comoros, and St Vincent and the Grenadines. 
Some flag states have been targeted for violations of multilateral rules where they are members of the relevant organisation. For example, in the cases of Panama (2012) and Sierra Leone (2016) the EU primarily based its decision on infringements of treaty obligations that these states had ratified at the time, such as the UNFSA or the regional body that they were members of. These are also clear cases of illegal fishing.

More interestingly, the EU has held two proceedings against states sponsoring unregulated fishing. The cases of Togo and Cambodia in Decision 354/01 of 15 November 2012 (the Decision) confirm that the EU is determined to target states whose vessels have operated against the rules adopted by regional fisheries organisations bodies despite not being members or ratifying the relevant regional treaties. 39

The Decision concerning Togo and Cambodia is mostly based on general rules enshrined in UNCLOS or in some of its provisions that are considered customary international law. Perhaps the most noteworthy aspect is that, beyond any considerations of the merits of the arguments presented, by equating their legal consequences the EU has made the difference between illegal and unregulated fishing close to meaningless.

(a) Decision on Togo

Paragraphs 340-383 of the Decision justify the EU's pre-identification or "yellow card" in respect to Togo. The country was for years a conspicuous flag of convenience, showing no will for controlling fishing vessels registered under its flag. The EU Decision presented ample evidence of at least 11 vessels flagged to Togo included in regional fisheries bodies' blacklists such as the International Commission for the Conservation of Atlantic Tunas (ICCAT), the Western and Central Pacific Fisheries Commission (WCPFC), the North East Atlantic Fisheries Commission (NEAFC), Northwest Atlantic Fisheries Organization (NAFO) and the Commission for the Conservation of Antarctic Marine Living Resources (CCAMLR). ${ }^{40}$ Interestingly, Togo is not a contracting party or cooperative non-member to any of these organisations and it is not a party to the UNFSA either. ${ }^{41}$ In

39 Commission Decision 354/01 on notifying the third countries that the Commission considers as possible of being identified as non-cooperating third countries [2012] OJ C354/1 [EU Decision]. The Decision notified eight states of "the possibility of being identified as third countries that the Commission considers as noncooperating third countries in fighting illegal, unreported and unregulated fishing": Sole Article. The eight countries were Belize, Fiji, Guinea, Panama, Sri Lanka and Vanuatu, in addition to Togo and Cambodia. This "yellow card" was lifted for Togo in October 2014, but Cambodia was identified and remains listed as of July 2018 as a "red card" country.

40 This article avoids the discussion on whether CCAMLR is a proper regional fisheries management organisation or not. Although there can be no doubt that originally CCAMLR did not qualify as a fisheries body, in practice it now fulfils a very similar role in its area of competence. For the purposes of this article and the assessment of state practice, CCAMLR is regarded as an international body with fisheries competence akin to regional fisheries management organisations.

41 UNCLOS is the only relevant agreement Togo has ratified. 
this sense, the activities of the Togolese fleet on the high seas were by all definitions unregulated fishing.

The reasons motivating the measures against Togo were essentially three violations of UNCLOS: flag state responsibilities under Article 94, the duty to cooperate to adopt conservation measures on the high seas under arts 117-118, and the general obligation on enforcement by flag states under Article 217.

On flag state responsibilities, the Decision was grounded on a broad interpretation of Article 94 of UNCLOS. Paragraph 350 of the EU Decision says that:

In this respect it is recalled that, pursuant to Article 94(1) and (2) of the UNCLOS, every State shall

effectively exercise its jurisdiction and control over ships flying its flag.

Article 94 refers primarily to the duties of the flag state to ensure safety at sea. However, it is under the general provisions of Part VII, and perhaps because of this the EU considered that the existence of vessels in the IUU lists of relevant regional fisheries organisations flagged to Togo was "a clear indication that Togo has failed to undertake its flag State responsibilities under international law". 42

Indeed, the International Tribunal for the Law of the Sea (ITLOS) recognised in 2015 that there is a link between Article 94 and the flag state responsibilities in terms of fisheries conservation. ${ }^{43}$ ITLOS concluded then that the flag state must, in fulfilment of its responsibilities to exercise effective jurisdiction and control in administrative matters: ${ }^{44}$

42 Regulation 1005/2008, above n 24, at [350].

43 Request for Advisory Opinion submitted by the Sub-Regional Fisheries Commission (Advisory Opinion) [2015] ITLOS Rep 4 at [117] and [119] [2015 Advisory Opinion]. Since art 194(2) of UNCLOS starts with the words "in particular", ITLOS concluded at [117] that "the list of measures that are to be taken by the flag states to endure effective exercise of its jurisdiction and control over ships flying its flag in administrative, technical and social matters is only indicative, not exhaustive". In his separate opinion, Judge Paik partially criticised and attempted to further develop this conclusion of the Tribunal. He stated that "there is no clear provision in the Convention that specifically addresses flag State obligations concerning IUU fishing, yet there have been significant legal developments related to this issue since the adoption of the Convention": Separate Opinion of Judge Paik at 104.

44 This is an obligation of conduct, not of result. At [129] of its 2015 Advisory Opinion, above n 43, ITLOS stated that "this is an obligation 'to deploy adequate means, to exercise best possible efforts, to do the utmost' to prevent IUU fishing by ships flying its flag. However, as an obligation 'of conduct' this is a 'due diligence obligation', not an obligation 'of result'. This means that this is not an obligation of the flag state to achieve compliance by fishing vessels flying its flag in each case with the requirement not to engage in IUU fishing ... The flag state is under the 'due diligence obligation' to take all necessary measures to ensure compliance and to prevent IUU fishing by fishing vessels flying its flag." ITLOS built upon previous jurisprudence by the International Court of Justice in Pulp Mills on the River Uruguay (Argentina v Uruguay) [2010] ICJ Rep 14; 
... adopt the necessary administrative measures to ensure that fishing vessels flying its flag are not involved in activities which will undermine the flag State's responsibilities under the Convention in respect of the conservation and management of marine living resources.

Under this interpretation, flag state responsibility is intrinsically connected to the conservation of marine living resources.

Although the 2015 ITLOS Advisory Opinion was aimed at activities occurring in the exclusive economic zone of a coastal state by vessels flagged to a foreign state, this criterion is perfectly valid in the wider context of the high seas. Yet even if this interpretation had been in place at the time of the EU Decision, it is not fully clear how Article 94 applies to the actions of Togo as a flag state on the high seas, except if one understands that the problem is precisely its failure to comply with the conservation and management measures adopted by regional organisations to which Togo is not a party and to which it has no obligation to become a member of or to cooperate with, at least under treaty law. Moreover, Togo is not a contracting party to the relevant agreements that explicitly enshrined the obligations of flag states regarding responsible fisheries on the high seas, including the 1993 FAO Compliance Agreement ${ }^{45}$ and the UNFSA. In this context, it is significant that for the EU the very fact that there were Togolese vessels in the IUU lists of regional fisheries bodies showed that: ${ }^{46}$

Togo has failed to exercise its responsibilities effectively, to comply with RFMO conservation and management measures and to ensure that its vessels do not engage in any activity which undermines the effectiveness of such measures.

This drafting clearly points at Togo's non-compliance with existing rules, which highlights the underlying rationale of this part of the EU Decision: fishing on the high seas disregarding the conservation measures adopted by the relevant regional fisheries organisation is a violation of flag state duties.

In respect of arts 117-118 of UNCLOS, the EU Decision noted at [352] that the number of IUU vessels carrying the flag of Togo "highlights the failure of Togo to fulfil its flag State obligations" of cooperation under UNCLOS. Although it was evident, the EU did not elaborate on how exactly Togo's behaviour was a breach of the UNCLOS duty to cooperate, but the same rationale suggested in the previous paragraphs holds true here: the EU measures were prompted because of the lack of cooperation with the relevant regional organisation. Therefore, if there is a standing regional body

and ITLOS Seabed Disputes Chamber in Responsibilities and obligations of states with respect to activities in the Area (Advisory Opinion) [2011] ITLOS Rep 10.

45 Agreement to Promote Compliance with International Conservation and Management Measures by Fishing Vessels on the High Seas 2221 UNTS 120 (opened for signature 24 November 1993, entered into force 24 April 2003).

46 EU Decision, above n 39, at [350]. 
with the legitimate mandate to adopt binding rules for the high seas, then fishing in that area is no longer acceptable unless the flag state is a member of that body or cooperates with it. The inclusion of Togolese vessels in the IUU lists showed that this obligation was not fulfilled and reveals the content of an obligation that goes beyond the more abstract "duty to cooperate" under arts 117-118 of UNCLOS.

Finally, the EU Decision also invoked Article 217 of UNCLOS on marine pollution, whereby states shall ensure compliance by vessels flying their flag with applicable international rules and standards for the prevention, reduction and control of pollution of the marine environment from vessels. Although this article is contained in Part XII of UNCLOS, which has not been traditionally associated to fisheries conservation and management, recent developments have confirmed the link between the conservation of marine living resources and the protection of the environment in a broad sense. ${ }^{47}$ Accepting and celebrating the recognition of this link, the EU Decision could have benefited from a more substantial analysis on how exactly the activities by the Togolese vessels violated the general duty enshrined in Part XII of UNCLOS. ${ }^{48}$

(b) Decision on Cambodia

In the case of Cambodia there were some additional legal complexities. Cambodia is neither a party to the UNFSA nor to any regional fisheries management organisation or body. Unlike Togo, Cambodia has not even acceded to UNCLOS. ${ }^{49}$ The unregulated activities addressed by the EU included two Cambodian-flagged vessels operating in Antarctic waters in 2010 with utter disregard for the rules adopted by CCAMLR as the relevant regional body. In general, the drafting of the Decision was like the case of Togo, ${ }^{50}$ but it needed legal arguments beyond the law of treaties to

47 Indeed, this link was first recognised in 1999 in the Southern Bluefin Tuna Case (New Zealand v Japan; Australia v Japan) (Provisional Measures) [1999] ITLOS Rep 280 at [70]: "the conservation of the living resources of the sea is an element in the protection and preservation of the marine environment". In its 2015 Advisory Opinion, above n 43, at [120] and [216] ITLOS recognised this interpretation, linking the duty to preserve the marine environment with arts 56 and 58 of UNCLOS and the rights and obligations applicable to states within the exclusive economic zone.

48 For example, the 2016 Award of the Arbitral Tribunal in the South China Sea Arbitration confirmed this interpretation and went further stating that "adopting appropriate rules and measures to prohibit a harmful practice is only one component of the due diligence required by states pursuant to the general obligation of Article 192, read in the context of Article 194(5) and the international law applicable to endangered species": South China Sea Arbitration (Philippines v China) (Award) PCA 2013-19 12 July 2016 at [964]. The Tribunal was referring to the harvesting of protected species such as marine turtles, giant clams and corals by Chinese fishermen. In the case of the IUU fishing activities by Togolese vessels, the EU Decision, above n 39, did not explicitly explain how this general duty to preserve the environment was contravened.

49 The EU Decision, above n 39, at [71] and [88] recognises that Cambodia did ratify the Convention on the High Seas 450 UNTS 11 (opened for signature 29 April 1958, entered into force 30 September 1962).

50 See for example EU Decision, above n 39, at [75], [77] and [82]-[83] on flag state responsibility and "the failure of Cambodia to honour its responsibilities". 
conclude that "the existence of IUU vessels" in the regional fisheries organisations lists that carried the flag of Cambodia "are clear indications that Cambodia has failed to undertake its flag State responsibilities under international law". 51

The Decision resorted to some UNCLOS provisions that were identified as customary international law. The Decision states that arts 86-115 "on the navigation in the high seas ... have been recognised as customary international law" and that, on this matter, the UNCLOS articles "codify pre-existing rules of customary international law and take over almost verbatim the wording of the Convention on the High Seas", which Cambodia has ratified. ${ }^{52}$ For this reason, "it is immaterial whether Cambodia has actually ratified" UNCLOS. There is nothing wrong in arguing that arts 91 and 94, or indeed arts 117-118 of UNCLOS are part of customary international law, as they highly likely are. But this assertion does not solve an important problem akin to the situation of Togo: the obligation to cooperate by ensuring that vessels do not engage in unregulated fishing on the high seas cannot be traced to UNCLOS, as it was first recognised in a general international instrument by the UNFSA. ${ }^{53}$ The arguments against Cambodia regarding its lack of cooperation and non-compliance with flag state responsibilities cannot be understood unless one interprets them as having the following specific content: that flag states have an obligation to cooperate with the relevant regional fisheries organisation and to control their vessels so that they comply with existing regulations adopted by such bodies.

(c) A positive assessment

There is much to praise in the EU Decision. If one considers some of these arguments as purely static they may look sometimes unconvincing. After all, the EU Decision had to circumvent the pacta tertiis rule and this is always a challenging obstacle in the language of treaty law. But the arguments put forward by the EU seem to show that the evolution of international fisheries law for the high seas is still in a state of flux. The notion of IUU fishing is often repeated like a mantra and indeed there is vagueness in its scope. Yet the underlying focus and motivation of the EU Decision regarding Togo and Cambodia seems to be the fundamental illegitimacy of unregulated activities on the high seas, and the efforts to bring them one step closer to illegality. It is here where the merits of the EU Decision rest: its long-term implications for combating IUU fishing and the progressive development of the legal tools available to such purpose. The United States' approach is not too far from that of the EU.

51 At [77].

52 EU Decision, above n 39, at [70].

53 Mercedes Rosello "Cooperation and unregulated fishing: interactions between customary international law, and the European Union IUU fishing regulation" (2017) 84 Marine Policy 306 at 308. 


\section{B Market Measures in Unilateral Practice: The United States Approach}

The United States has also envisaged a system with roughly the same two broad elements described in the case of the EU: a traceability scheme and an identification process aimed at targeting non-compliant third countries. As in the EU case, this article is only concerned with the latter.

\section{Process for identification and sanctioning third countries}

The Magnuson-Stevens Fishery Conservation and Reauthorization Act $2006^{54}$ introduced substantive modifications in the United States legal fisheries framework, including on ss 603-610 of the High Seas Driftnet Fishing Moratorium Protection Act 1992 (the Moratorium Protection Act). ${ }^{55}$ Sections 607 and 609 of the Moratorium Protection Act, as amended, require the Secretary of Commerce to publish a biennial report to Congress, identifying and listing countries that are or have been engaged in the preceding two years in IUU fishing. ${ }^{56}$ If the identified countries fail to take actions they receive a negative certification. ${ }^{57}$ In this case, they will face sanctions under the High Seas Driftnet Fisheries Enforcement Act 1992, including prohibition of imports to the United States. ${ }^{58}$ The relevant administrative authority, the National Marine Fisheries Service of the National Oceanic and Atmospheric Administration (NOAA), published in 2011 a Final Rule on the procedure to implement the identification and certification provisions of the Moratorium Protection Act, including for unregulated fishing. ${ }^{59}$ The 2011 procedure was modified in 2013, with some changes in the definition of "IUU fishing" that made clear the intention to reach activities undertaken by non-members of regional fisheries organisations to which the United States is a party. ${ }^{60}$

\section{The United States domestic definitions of unregulated fishing activities}

Unlike the EU, the United States has adopted in practice two different definitions for unregulated activities, depending on the purposes for each one. The simplest one relates to the domestic implementation of the 2009 FAO Port State Measures Agreement. In implementing this treaty, the

$54 \quad 16$ USC $\S 1801$.

55 More recently, the Shark Conservation Act 2010 and the Illegal, Unreported, and Unregulated Fishing Enforcement Act 2015 also amended the Moratorium Protection Act.

5616 USC $\S 1826 \mathrm{~h}$ and $\S 1826 \mathrm{j}$. This is also extended to fishing activities resulting in bycatch of species protected, as defined by the Moratorium Protection Act.

5716 USC $\S 1826 \mathrm{j}(\mathrm{d})$. The Secretary of Commerce must certify to Congress whether an identified nation has taken appropriate corrective action to address the activities for which it has been identified. In practice, after notifying the countries of their identifications, the United States Government consults extensively with the authorities of those countries.

58 High Seas Driftnet Fishing Moratorium Protection Act 16 USC 1826d.

5950 CFR § 300, Federal Register Vol 76 No 8 (12 January 2011) at 2011.

6050 CFR § 300.201, Federal Register Vol 78 No 11 (16 January 2013) at 3338 and 3342. 
Illegal, Unreported, and Unregulated Fishing Enforcement Act 2015 defined unregulated fishing with full reference to the 2001 FAO Plan of Action. ${ }^{61}$

In addition to this first definition, the Moratorium Protection Act had established a concept for unregulated fishing within the more limited scope of the identification of foreign nations whose vessels have engaged in IUU fishing. Section 609(e)(1)-(3) asserts that the Secretary of Commerce shall publish a definition of the term "illegal, unreported, or unregulated fishing" for purposes of this Act, ${ }^{62}$ and that the Secretary shall include certain guidelines as a minimum. ${ }^{63}$ The subsequent Secretary's definition shows that the United States includes under the notion of unregulated fishing activities from contracting parties and non-members to the relevant regional fisheries agreement as long as the United States is a party itself. ${ }^{64}$ Confirmation of this approach is the Final Rule adopted by the National Marine Fisheries Service in January 2013, where s 300.201 says that "illegal, unreported and unregulated (IUU) fishing means":65

(2) In the case of non-parties to an international fishery management agreement to which the United States is a party, fishing activities that would undermine the conservation of the resources managed under the agreement.

6116 USC $\S 7402.2$ : "The term 'IUU fishing' means any activity set out in paragraph 3 of the 2001 FAO International Plan of Action to Prevent, Deter and Eliminate Illegal, Unreported and Unregulated Fishing."

6216 USC $\S 1826$ j. Section 609 was added by s 403 of the Reauthorisation Act.

6316 USC $\$ 1826 \mathrm{j}(\mathrm{e})(3)$. The definition of unregulated fishing must include: "(A) fishing activities that violate conservation and management measures required under an international fishery management agreement to which the United States is a party, including catch limits or quotas, capacity restrictions, bycatch reduction requirements, and shark conservation measures; (B) overfishing of fish stocks shared by the United States, for which there are no applicable international conservation or management measures or in areas with no applicable international fishery management organization or agreement, that has adverse impacts on such stocks; and (C) fishing activity that has an adverse impact on seamounts, hydrothermal vents, and cold water corals located beyond national jurisdiction, for which there are no applicable conservation or management measures or in areas with no applicable international fishery management organization or agreement."

6450 CFR $\S 300$, above n 59, at 2024.

6550 CFR $\S 300.201$, above n 60, at 3342-3343. This is also confirmed by the last 2017 report: United States Department of Commerce Improving International Fisheries Management: Report to Congress Pursuant to Section 403(a) of the Magnuson-Stevens Fishery Conservation and Management Reauthorization Act of 2006 (January 2017) at 19. In relation to activities "Undermining RFMO Conservation by Non-Parties" on the high seas, it expressly states: "Under this aspect of the IUU fishing definition, a nation may be identified for fishing activities that undermine the conservation of resources under an international fishery management agreement to which the United Sates is a party, despite the fact that a nation is not a party to the agreement." Past Biennial Reports to the United States Congress are consistent with this approach. The express recognition of this intention by the executive branch of the United States Government, in a formal communication to Congress, clearly underlines the intention and potential reach of the United States scheme. 
Therefore, the key component of the notion of unregulated fishing is maintained, as it refers to states that are neither party nor cooperating non-members of the relevant regional fisheries body.

\section{Appling the United States measures to third-party states}

There have been few cases in the practice and implementation of the United States legislation linked to what is strictly speaking unregulated fishing. The Secretary of Commerce presented the first biennial report to Congress in 2009 and subsequent reports in 2011, 2013, 2015 and 2017. Although the last 2017 report could only identify illegal activities coming from states party to the relevant regional fisheries bodies, ${ }^{66}$ past reports did refer to unregulated activities. The 2015 report identified and certified six foreign states. ${ }^{67}$ Nigeria was included for violations of conservation measures adopted by CCAMLR, to which it was not a contracting party. However, as Nigeria has been a contracting party to the UNFSA since 2009, it could be argued that they were not unregulated activities because the relevant treaty provisions apply. ${ }^{68}$ Rather than being unregulated, the activities by the Nigerian-flagged vessels may be considered as illegal. ${ }^{69}$

Two better examples are found in the 2009 and 2013 biennial reports. The 2009 report identified Panama as having two vessels operating around the Northwest Atlantic Fisheries Organization area in 2007 and $2008 .{ }^{70}$ Panama is not a member of this organisation, and it acceded to the UNFSA only in December 2008. At the time of the infringements reported to the United States Congress, Panama's activities in the Northwest Atlantic Fisheries Organization area were thus fully unregulated.

More recently, the 2013 report identified Tanzania as four of its vessels were included in the list of non-Contracting Parties vessels engaged in IUU fishing activities in CCAMLR, and "they

66 Ecuador in respect of the Inter-American Tropical Tuna Commission (IATTC) and Russia in CCAMLR. United States Department of Commerce Improving International Fisheries Management: Report to Congress (January 2017) at 24.

67 United States Department of Commerce Improving International Fisheries Management: Report to Congress Pursuant to Section 403(a) of the Magnuson-Stevens Fishery Conservation and Management Reauthorization Act of 2006 (February 2015).

68 UNFSA, arts 8(3)-(4) and 17.

69 This is assuming that CCAMLR can be regarded as a regional fisheries management organisation for the application of the UNFSA provisions, which is far from clear. Therefore this statement is not free from criticism and indeed deserves more analysis, which is beyond the scope of this article. However, if CCAMLR cannot be considered as a body to which the UNFSA provisions apply, the activities undertaken by Nigerianflagged vessels are then plainly unregulated.

70 United States Department of Commerce Improving International Fisheries Management: Report to Congress Pursuant to Section 403(a) of the Magnuson-Stevens Fishery Conservation and Management Reauthorization Act of 2006 (January 2009) at 94. 
undermined the effectiveness of CCAMLR conservation measures". ${ }^{71}$ Tanzania is not a member of the CCAMLR Commission, is not a contracting party to the CCAMLR Convention and it has not ratified the UNFSA.

These two last cases highlight the unequivocal will of the United States to adopt trade restrictive measures for fishery products coming from unregulated activities. Unlike the EU - which attempted to find an explicit legal rationale for the countries identified as undertaking unregulated activities the United States has not particularly focused on the legal argumentation of the identification decisions. What remains important is that both schemes have proven effective tools to target unregulated fishing. The practical consequence is evident: the United States and the EU have treated fishing by vessels flagged to non-parties to the relevant regional fisheries organisation as subject to the same measures and consequences as those they apply to illegal fishing.

\section{TIME FOR CHANGE? THE EUROPEAN UNION AND UNITED STATES ACTION AS RELEVANT PRACTICE FOR THE FORMATION OF CUSTOMARY INTERNATIONAL LAW}

The cases introduced above show a strong determination by two of the most important world market destinations for fishery products to tackle unregulated fishing. Beyond the merits or possible pitfalls of the legal argumentation presented by the EU, and notwithstanding the lack of explicit justification for the United States' actions, what these two cases show is that unilateral actions against non-party states are a reality. This entails, in practice, equating unregulated fishing to illegal fishing despite the challenge represented by the pacta tertiis rule.

\section{An emerging customary international rule?}

One possible explanation for the EU and United States' measures - and the apparent acceptance of those targeted by them - lies in the recent emergence of a new customary rule prohibiting unregulated fishing. In other words, these actions suggest that the hard core of the obligations recognised in arts 8(3)-(4) and 17 in the UNFSA concerning non-parties to regional fisheries bodies is becoming customary; either a state is a member of the regional fisheries organisation or cooperates to apply its rules, or the vessels flagged to that state shall refrain from fishing. If this has indeed been realised, it would mean that a violation of the multilateral measures adopted by regional fisheries bodies by non-party vessels would trigger the responsibility of the flag state, and all the consequences of breaching a primary rule of international law.

This question is not new. For example, Erik Molenaar suggested in 2004 that "the strengthened duty to co-operate with [regional fisheries organisations] pursuant to Article 8(3) of the [UNFSA] has

71 United States Department of Commerce Improving International Fisheries Management: Report to Congress Pursuant to Section 403(a) of the Magnuson-Stevens Fishery Conservation and Management Reauthorization Act of 2006 (January 2013) at 30. 
already evolved into customary international law". ${ }^{72}$ However, he warned that an authoritative confirmation of the correctness of this assertion might not be available until such time as these organisations accept the need for bolder measures against non-cooperating non-members. ${ }^{73}$ Rosemary Rayfuse argued in 2005 that the key treaty provisions of the UNFSA prohibiting unregulated fishing had become customary and therefore binding on every member of the international community. ${ }^{74}$ Referring to this duty, she asserted that "it is arguable that [it] may now be binding on all States as a matter of customary international law". ${ }^{75}$ She was later more cautious and avoided concluding that there was a rule binding on all states. ${ }^{76}$

Other scholars reject this claim, questioning whether state practice and opinio juris are ripe enough for such an allegation. ${ }^{77}$ Despite the different views about the status of this emerging rule, it seems that in general scholars do not deny that a prohibition on unregulated fishing on the high seas could potentially emerge as customary. For example, Andrew Serdy stated that some of the provisions of the UNFSA, including Article 8, "are certainly susceptible of transformation into custom". ${ }^{78} \mathrm{He}$ recently recognised that "these days there is a reasonably strong argument to be made for the case" that Article 8(3)-(4) of the UNFSA have become customary, although he warns of the problems this outcome represents if there is no recognition of the right of new entrants to the fishery as part of the same rule. ${ }^{79}$

Concluding whether a customary rule prohibiting unregulated fishing on the high seas has materialised into customary law is certainly beyond the scope of this article. Such a task would entail assessing the development of the two constitutive elements of customary law, state practice and opinio

72 EJ Molenaar "Unregulated Deep-Sea Fisheries: A Need for a Multi-Level Approach" (2004) 19 IJMCL 223 at 231 .

73 At 231

74 Rosemary Rayfuse "To Our Children's Children's Children: From Promoting to Achieving Compliance in High Seas Fisheries" (2005) 20 IJMCL 509. She refers to art 8(3)-(4) of the UNFSA.

75 At 525 .

76 Rosemary Rayfuse "Non-flag State Enforcement and Protection of the Marine Environment: Responding to IUU Fishing" in Myron H Nordquist and others (eds) Freedom of Seas, Passage Rights and the 1982 Law of the Sea Convention (Martinus Nijhoff Publishers, Leiden, 2009) 573.

77 Theilen, above n 5; and Moritaka Hayashi "Regional Fisheries Management Organisations and NonMembers" in Tafsir Malick Ndiaye and Rudiger Wolfrum (eds) Law of the Sea, Environmental Law and Settlement of Disputes: Liber Amicorum Judge Thomas A Mensah (Martinus Nijhoff Publishers, Leiden, 2007) 751. More recently, see also Rosello, above n 53, at 308.

78 Andrew Serdy "Postmodern International Fisheries Law, or We Are All Coastal States Now" (2011) 60 ICLQ 387 at 389.

79 Andrew Serdy "Pacta Tertiis and Regional Fisheries Management Mechanisms", above n 5, at 349-350. The scope of his argument certainly exceeds the purpose of this article. 
juris. If such a rule is not consolidated but at least emerging, the point this article makes is simple: the unilateral actions by the EU and the United States should be regarded as relevant practice underpinning or influencing a potential customary change in the law of the high seas, whereby fishing against the rules of regional fisheries bodies by vessels flagged to non-member states is regarded and treated as illegal.

To postulate that the actions by the EU and the United States represent state practice shaping a change in the international law of the high seas needs certain clarifications. Although international customary law may be difficult to identify, it certainly exists and is still a relevant, universal source of international law with a key systemic role to play. Problems may lie as to the method to identify a new or emerging rule. Deductive approaches, for example, are usually detached from a sense of reality (utopian) and based on considerations in close interplay between law and moral values. ${ }^{80}$ These approaches are clearly unsuited for the case of unregulated fishing, even if the sustainable exploitation of marine biodiversity is not necessarily exempt from moral considerations. To avoid aspirational claims, the work of the International Law Commission ${ }^{81}$ should be a reasonable starting point - closer to a classic, inductive methodology - yet some of its ambiguities may need clarification against the positions adopted by scholarly works such as the International Law Association and others. ${ }^{82}$

\section{Content of state practice}

There should be no doubt that the actions taken by both the EU and the United States constitute state practice in a material sense. Draft conclusion 6(7) of the International Law Commission on forms of practice says that "[m]anifestations of practice include, among others" conduct in connection with treaties and legislative and administrative acts. ${ }^{83}$ State practice, as a fundamental element of customary international law, means that it must be general, uniform and consistent over a certain period of time. ${ }^{84}$ The actions taken by the EU and the United States may not have reached that status

80 This is sometimes the case with international criminal and humanitarian law, and to a certain point with international human rights. As way of example, the approach of the International Court for the Former Yugoslavia in the Kupreskic case has been often quoted. Here the Tribunal held that the opinio element could crystallise "as a result of imperatives of humanity or public conscience" and it "may turn out to be the decisive element heralding the emergence of a general rule or principle of humanitarian law": Prosecutor v Kupreskic (Judgment) ICTY Trial Chamber IT-95-16-T, 14 January 2000 at [527].

81 Report of the International Law Commission on the work of its sixty-eighth session UN Doc A/71/10 (22 February 2016) at [50]-[63].

82 See International Law Association London Statement of Principles Applicable to the Formation of General Customary Law Resolution 16/2000: Formation of General Customary International Law (adopted at the sixty-ninth Conference of the International Law Association, London, 29 July 2000) [London Statement].

83 Michael Wood Second report on identification of customary international law UN Doc A/CN.4/672 35 (2014) at [48].

84 At [15]-[41]. See also London Statement, above n 82, at 20-29; and James Crawford Brownlie's Principles of Public International Law (8th ed, Oxford University Press, Oxford, 2012) at 24-25. 
yet, but they would probably need to be assessed and compared along other relevant pieces of practice at both multilateral and unilateral levels.

An additional important point to make here is that practice coming from the EU and United States is relevant because they may be regarded as specially-affected states. ${ }^{85}$ The International Court of Justice put it clearly in the North Sea Continental Shelf Cases: when assessing whether a rule contained in a treaty has passed into custom, the Court said that widespread and representative participation in the treaty might suffice provided it included that of states whose interests were specially affected. ${ }^{86}$ The actions and inactions of these states are critical to ascertain what sort of state practice needs more attention. And yet for all the importance attached to this notion by the North Sea Continental Shelf Cases, the concept was not developed or mentioned again by the International Court of Justice, and it has not received as much attention by scholars at it deserves. ${ }^{87}$

The whole international community has an interest in the regulation of the common goods, but not every state has fishing vessels operating under its flag on the high seas and this basic fact is significant for the development of customary law in international fisheries. Coastal nations whose vessels operate for straddling or highly migratory stocks are relevant states in the sense that any emerging or new customary rule may affect their interests. The same happens with distant water nations and entities that have maintained a regular presence on the high seas. Indeed, some of them are at the same time coastal and distant water fishing states. Equally important, practice should include the so-called flags of convenience, as they are the main target of the likely sanctions by market destinations such as the EU and United States: silence and acquiesce should be interpreted as a step in the formation of a new rule. Although all these states would be affected by any change on the legal framework for high seas fisheries, it does not mean that their interests should be considered automatically as specially affected.

85 The article assumes that the practice of the European Commission regarding fisheries and related to the EU Fisheries Policy represents, at least partially, the practice of its member states. Article 3 of the Lisbon Treaty asserts that "The Union shall have exclusive competence in the following areas: (d) the conservation of marine biological resources under the common fisheries policy": Treaty of Lisbon Amending the Treaty on European Union and the Treaty Establishing the European Community 2702 UNTS 1 (signed 13 December 2007, entered into force 1 December 2009).

86 North Sea Continental Shelf Cases (Federal Republic of Germany/Denmark, Federal Republic of Germany/Netherlands) (Merits) [1969] ICJ Rep 3 at 43: "With respect to the other elements usually regarded as necessary before a conventional rule can be considered to have become a general rule of international law, it might be that, even without the passage of any considerable period of time, a very widespread and representative participation in the convention might suffice of itself, provided it included that of States whose interests were specially affected."

87 A recent exception is the contribution by Kevin Jon Heller "Specially-affected states and the formation of custom" (2018) 112 AJIL 191. Although mostly focused on international humanitarian law, see also Shelly Aviv Yeini "The Specially-Affecting States Doctrine" (2018) 112 AJIL 244. 
Having said that, in the context of this article there seems to be good reasons to apply the notion of specially-affected states to the United States and the EU, at least prima facie, as they are at the same time coastal states, distant water fishing players - strongly in the case of the EU - and the two biggest market destinations for fishery products. ${ }^{88}$ This recognition does not, of course, prevent the existence of further specially-affected states, including those that may oppose any customary change on the high seas. Its potential importance should be immediately qualified by the assertion that the status of specially-affected state does not confer any veto power in the development of customary international law. 89

\section{The relationship between treaty and customary international law}

Just as the North Sea Continental Shelf Cases did almost 50 years ago, ${ }^{90}$ Draft Conclusion 11(12) of the International Law Commission work recognises that a treaty may codify an existing customary rule, lead to its crystallisation, or give rise to a general practice accepted as law. ${ }^{91}$ The last situation aptly describes the case of the prohibition of unregulated fishing on the high seas, for some provisions of the UNFSA indeed contain the core obligation that may be emerging as custom (Articles 8(3)-(4) and 17).

When it comes to analysing whether a treaty provision has become or is becoming customary, the issue of membership to treaties becomes relevant. In the case of the unilateral measures adopted by the EU and the United States, they have mostly targeted states that are members to the relevant fisheries organisations or are part of the UNFSA. There is agreement that this sort of practice is not enough to advance a customary change: they should be understood as requests to perform treaty obligations. The practice that counts is that of non-members, or that of treaty parties interacting with non-contracting parties. As Crawford has demonstrated, treaty participation is simply not enough to develop customary international law. ${ }^{92}$ This is the reason why the EU and United States actions presented in this article are relevant: it is practice outside the context of treaty obligations and vis-àvis non-parties. The unilateral measures adopted against non-members states such as Togo, Cambodia and Tanzania - and their reactions or acquiescence - prove that such specific practice can occur.

88 The State of World Fisheries and Aquaculture 2018, above n 1, at 21.

89 KJ Heller correctly stated that: "Such power is irreconcilable, however, with even the thinnest understanding of sovereign equality. Giving specially-affected States more power over custom formation than non-speciallyaffected States is one thing; permitting one specially-affected state to block the formation of a customary rule that is supported by every other specially-affected state is quite another." Heller, above n 87, at 233-234

90 North Sea Continental Shelf Cases, above n 86, at 39.

91 International Law Commission Text of the draft conclusions provisionally adopted by the Drafting Committee, Identification of customary international law UN Doc A/CN.4/L.872 (30 May 2016).

92 James Crawford "Chance, Order, Change: The Course of International Law" (2013) 365 Recueil des Cours 9 at 107. 


\section{How to measure opinio juris}

The belief that an action or omission is an obligation - or a right - under international law is often captured in the notion of opinio juris. Many of the difficulties in understanding contemporary customary international law derive from the need to accommodate this rather obscure notion. ${ }^{93}$ Yet one certainty is the impossibility of entirely disregarding opinio. ${ }^{94}$ The complexities range from identifying a proper belief inside the state ${ }^{95}$ to the more philosophical questions about why customary law should be binding. ${ }^{96}$

The actual content of opinio is the subject of a never-ending debate with a wide array of different narratives by scholars. ${ }^{97}$ A generally accepted and adequately realistic view suggests that opinio develops over a dialectic process: it moves forward initially by some states articulating a new rule backed by action and the responses by other members of the international community over time, including acceptance, acquiescence or rejection. ${ }^{98}$ As Mendelson rightly depicts it, consent may be a sufficient condition for being bound, but it has never been a necessary condition. ${ }^{99}$ Therefore, the subjective element does not necessarily need to exist at the formation of the customary rule. ${ }^{100}$ Indeed, the case of unregulated fishing seems to confirm that opinio juris behaves differently depending on the development stage of the rule in question. The search for the subjective element should not necessarily look for a well-established belief of obligation.

93 The expression does not have a literal Roman origin and it does not have a clear meaning. James Crawford calls this element "an interloper": Crawford, above n 84, at 52.

94 Although a minority, some scholars argue that "opinio" is the central element in the formation of custom. See Tullio Treves "Customary International Law" in R Wolfrum (ed) Max Planck Encyclopedia of Public International Law (Oxford University Press, 2012) 937 at 939.

95 Michael Akehurst "Custom as a Source of International Law" (1975) 47 British Yearbook of International Law 1 at 36 and 37. He criticises the idea of "belief".

96 Karol Wolfke Custom in Present International Law (2nd ed, Martinus Nijhoff Publishers, Dordrecht, 1993) at 160-168; and Gerald Postema "Custom in International Law as a Normative Practice" in A PerreauSaussine and JB Murphy (eds) The Nature of Customary International Law: Legal, Historical and Philosophical Perspectives (Cambridge University Press, New York, 2007) 279 at 282.

97 The list of references would be extensive. For some of the most authoritative accounts see Maurice $\mathrm{H}$ Mendelson "The Formation of Customary International Law" (1998) 272 Recueil des Cours 155 at 195-196; Hugh Thirlway The Sources of International Law (Oxford University Press, Oxford, 2014) at 56-57; Crawford, above n 84; and Alain Pellet "Article 38" in A Zimmermann and others (eds) The Statute of the International Court of Justice: A Commentary (2nd ed, Oxford University Press, Oxford, 2012) 731.

98 Crawford, above $\mathrm{n} 84$, at 66.

99 Mendelson, above n 97, at 260.

100 See for example London Statement, above n 82, at 7-10. 
This contextualisation helps to understand why the EU and United States' actions should not be measured against the high bar of a consolidated belief on the prohibition against unregulated fishing on the high seas. Opinio should be therefore assessed and understood as an evolving belief rather than a positive and clear sense of obligation. The bilateral and multilateral actions of specially-affected states such as the trade measures applied by the EU and the United States are key steps in the development of this belief, for it is practice coming from contracting parties to the UNFSA and the regional fisheries treaties vis-à-vis states that are not party or members to them. In the same vein, the reactions by those states targeted by the EU and United States are also relevant: in the present case, they seemed to have responded with either acceptance or acquiescence.

\section{CONCLUSIONS}

This article has offered a case that shows how unilateral measures adopted by two relevant state actors may prompt change in the international law of the high seas.

The unilateral trade measures adopted by the EU and the United States and explored in this article are novel in the sense that they have equated unregulated fishing with illegal fishing in terms of the legal consequences attached to them. The EU and United States' measures have in practice blurred this distinction or plainly rendered it irrelevant.

This article has suggested that the EU and United States' trade measures should be regarded as relevant state practice advancing a general prohibition against unregulated fishing on the high seas. The material content of the practice, the likely condition of the United States and the EU as speciallyaffected states and their interactions vis-à-vis treaty non-members are all important aspects that contribute to a customary change. These unilateral measures should also be regarded as potentially influencing an evolution in opinio juris, which should not be interpreted as a search for a consolidated sense of legal obligation or belief while the new rule is developing or emerging.

The question of whether such a rule exists in customary international law is not new and this article has not attempted to answer it. Rather, it has argued that the EU and United States' trade measures against unregulated fishing are a form of state practice that is relevant for its formation. Whether there is an emerging or materialising customary rule against unregulated fishing on the high seas remains to be adequately explored and assessed. What is certain is that state practice is evolving, and depending on its generality, consistency and uniformity over time, it might signal the end of the freedom to fish as it has been understood since the adoption of UNCLOS. 
